\title{
Supremo Tribunal Federal e prerrogativa de foro
}

\section{Alexandre de Moraes*}

O presente estudo foi apresentado na forma de Parecer Jurídico para análise de questões constitucionais nos autos da Ação Penal no 470, ajuizada pelo Excelentíssimo procurador-geral da República perante o EGRÉGIO SUPREMO TRIBUNAL FEDERAL.

O estudo deveria conter a ampla análise das características, abrangência e aplicação da competência penal originária do SUPREMO TRIBUNAL FEDERAL, bem como de sua possibilidade ou não de ampliação pela legislação ordinária. Solicitou-se, ainda, a análise da aplicabilidade ou não das regras processuais penais ordinárias (conexão e continência) em face da previsão constitucional de prerrogativa de foro em razão de função (CF, art. 102, I, "b" e "c") e dos Princípios do Juiz Natural e do Devido Processo Legal.

Foram apresentados os seguintes quesitos a serem analisados:

QUESITO 1 - É possível ao legislador ordinário ampliar as competências originárias do Supremo Tribunal Federal?

QUESITO 2 - É possível a ampliação das competências originárias do Supremo Tribunal Federal com base na Teoria dos Poderes Implícitos?

* Alexandre de Moraes é advogado e consultor jurídico. Chefe do Departamento de Direito do Estado da Faculdade de Direito da USP, onde é professor associado. Doutor em direito do estado e livre-docente em direito constitucional. Foi promotor de Justiça (1991-2002), secretário de Estado da Justiça e Defesa da Cidadania (2002-2005), membro da 1aㅡ Composição do Conselho Nacional de Justiça (2005-07) e secretário municipal de Transportes e de Serviços de São Paulo (2007-10). Autor de várias obras, entre elas Direito constitucional, Constituição do Brasil interpretada e Legislação constitucional e direitos humanos fundamentais. 
QUESITO3 - É possível a ampliação das competências penais originárias do Supremo Tribunal Federal com base em interpretação de legislação ordinária já existente (regras legais de conexão e continência), permitindo que a Corte processe e julgue réus não previstos no art. 102, inciso I, " $b$ " e " $c$ " da Constituição Federal?

QUESITO 4 - A Súmula 704 do Supremo Tribunal Federal ("não viola as garantias do juiz natural, da ampla defesa e do devido processo legal a atração por continência ou conexão do processo do corréu ao for por prerrogativa de função de um dos denunciados") se aplica em relação às competências penais originárias da Corte?

\section{(I) Excepcionalidade e taxatividade das competências originárias do Supremo Tribunal Federal - impossibilidade de ampliação pela legislação ordinária}

A definição de competências penais originárias do SUPREMO TRIBUNAL FEDERAL é consubstanciada nas alíneas " $\mathrm{b}$ " $\mathrm{e}$ " $\mathrm{c}$ ", do inciso I, do artigo 102 da Constituição da República Federativa do Brasil; seguindo tradição em nosso Direito Constitucional na previsão de competência de nossa mais alta CORTE para o processo e julgamento das infrações penais comuns de altas autoridades da República, na denominada "prerrogativa de foro em razão da função", ou simplesmente, "foro privilegiado".

A excepcionalidade das competências originárias do SUPREMO TRIBUNAL FEDERAL exige previsão expressa e taxativa do texto constitucional, conforme princípio tradicional de distribuição de competências jurisdicionais nascido com o próprio constitucionalismo norte-americano em 1787.

A previsão de competências originárias das SUPREMAS CORTES, taxativamente previstas pelos textos constitucionais, nasceu conjuntamente com a ideia de Supremacia Jurisdicional por meio do controle de constitucionalidade, ambas sendo firmadas no célebre caso Marbury v. Madison (1 Cranch 137 1803), em histórica decisão da Suprema Corte americana, relatada por seu Chief Justice JOHN MARSHALL, que envolvia não só conflitos jurídicos, mas também políticos, pois a Suprema Corte era composta majoritariamente de federalistas, enquanto o Congresso e o Executivo estavam sob o controle dos republicanos, que jamais aceitariam uma intervenção direta do Judiciário nos negócios políticos do Executivo (Cf. a respeito: HENRY J. ABRAHAM. A Corte Suprema no evolutivo processo político. In: Vários autores. Ensaios sobre 
a Constituição dos Estados Unidos. Rio de Janeiro: Forense Universitária, 1978. p. 93. THOMAS COOLEY. Princípios gerais de direito constitucional dos Estados Unidos da América do Norte. 2. ed. São Paulo: Revista dos Tribunais, 1982. p. 142; LAWRENCE BAUM. A Suprema Corte americana. Rio de Janeiro: Forense Universitária, 1987. p. 132).

Marbury havia sido nomeado em 1801, nos termos da lei, para o cargo de juiz de paz no Distrito de Columbia, pelo então Presidente da República John Adams, do Partido Federalista, que se encontrava nos últimos dias de seu mandato.

Ocorre, porém, que não houve tempo hábil para que fosse dada a posse ao já nomeado Marbury, antes que assumisse a Presidência da República o republicano Thomas Jefferson. Este, ao assumir, determinou que seu Secretário de Estado, Madison, negasse posse a Marbury, que por sua vez, em virtude dessa ilegalidade, requereu à Suprema Corte um mandamus, para que o Secretário de Estado Madison fosse obrigado a dar-lhe posse.

Marshall, de forma hábil, tratou o caso pelo ângulo da competência constitucional originária da Suprema Corte Americana (KERMIT L. HALL. The Oxford guide to United States Supreme Courts decisions. New York: Oxford University Press, 1999. p. 173; CARL BRENT SWISHER. Decisões históricas da Corte Suprema. Rio de Janeiro: Forense, 1962. p. 10-14; BERNARD SCHWARTZ. Direito constitucional americano. Rio de Janeiro: Forense, 1966. p. 257), analisando a incompatibilidade da Lei Judiciária de 1789, que autorizava o Tribunal a expedir mandados para remediar erros ilegais do Executivo, e a própria Constituição, que em seu artigo III, seção 2, disciplinava a competência originária da Corte.

Como declarou o CHIEF JUSTICE MARSHALL, em Marbury v. Madison (1 Cranch 137 - 1803), único caso em que sua Corte teve a oportunidade de aplicar o controle jurisdicional de constitucionalidade,

a questão de que uma lei em choque com a Constituição possa transformar-se em Direito do País é profundamente interessante para os Estados Unidos e, felizmente, não tão confusa quanto a proporção de seu interesse. Parece apenas necessário reconhecer certos princípios considerados há muito como bem estabelecidos, para decidir. Que o povo tem um Direito originário de estabelecer, para seu futuro governo, tais princípios, que, em sua opinião, provavelmente melhor conduzirão à sua felicidade, é a base sobre a qual toda a estrutura americana tem sido erigida. O exercício desse Direito original demanda um enorme esforço; 
não pode nem deve ele ser frequentemente repetido. Os princípios, portanto, assim estabelecidos, são considerados fundamentais; e como autoridade da qual promanam é suprema e raramente pode agir, são designados para ser permanentes. Essa vontade original e suprema organiza o governo e determina aos diversos departamentos seus respectivos poderes. Pode parar aqui ou estabelecer certos limites que não devem ser transcendidos por aqueles departamentos. O Governo dos Estados Unidos segue a última ideia. Os poderes do Legislativo são definidos e limitados e seus limites não podem ser controvertidos ou enfraquecidos; a Constituição é escrita. Qual o propósito de serem os poderes limitados e aqueles limites consignados por escrito, se puderem, a qualquer tempo, ser ultrapassados por limites considerados como restritos? A distinção entre um governo com poderes limitados ou ilimitados é abolida, se aqueles limites não contiverem as pessoas sobre as quais são impostos, e se leis proibidas e leis permitidas forem de igual obrigação. É uma proposição demasiadamente clara para ser contestada, a de que a Constituição controla qualquer ato legislativo em choque consigo, ou que o Legislativo possa alterar a Constituição por lei ordinária. Entre estas alternativas, não há meio-termo.

MARSHALL prosseguiu em sua fundamentação, afirmando que:

a Constituição é um chefe superior, do Direito, imutável por meios ordinários, ou estará num mesmo nível com as leis ordinárias e, como as outras, poderá ser alterada quando o Legislativo quiser. Se a primeira parte da alternativa é verdadeira, então a lei legislativa contrária à Constituiçãonãoé Direito; se aúltima parteé certa, então as Constituições escritas são tentativas absurdas, por parte do povo, de limitar um poder, por sua própria natureza ilimitado. Certamente, todos os que têm fundado Constituições escritas contemplam-nas como formadoras do Direito fundamental e supremo da Nação, consequentemente, abraçam a teoria de que cada governo deve aceitar que uma lei ordinária em conflito com a Constituição é inoperante. Essa teoria é essencialmente una à Constituição escrita e deve, portanto, ser considerada por essa Corte como um dos princípios fundamentais de nossa sociedade. Não devemos, portanto, perdê-lo de vista em posteriores considerações desse assunto. Se uma lei ordinária inconstitucional for revogada, sua invalidade, todavia, vai às Cortes, e obriga-as a dar-lhe efeito? 
Ou, em outras palavras, embora não constitua Direito, será uma norma tão operativa quanto se fosse Direito? Isso seria anular, de fato, o que foi estabelecido na doutrina; pareceria, à primeira vista, um absurdo demasiadamente grosseiro para que se insista nele. Receberá, entretanto, uma consideração mais atenta. É da competência especial, bem como o dever do Poder Judiciário, dizer o que é o Direito. Aqueles que aplicam a regra a casos particulares devem, necessariamente, expor e interpretar aquela regra. Se duas leis entram em conflito, os tribunais devem decidir sobre a aplicação de cada uma.

Após a explanação sobre a Supremacia da Ordem Constitucional, apontou o CHIEF JUSTICE MARSHALL, que:

se uma lei opuser-se à Constituição e se ambas, a lei e a Constituição, aplicam-se a um caso particular, de modo que a Corte deva decidir aquele caso conforme a lei, desrespeitando a Constituição ou respeitála, recusando a lei, a Corte deve determinar qual dessas regras em conflito governa o caso; isto é da própria essência do dever judiciário. Se, então, os tribunais quiserem respeitar a Constituição, e esta for superior a qualquer lei ordinária do Congresso, a Constituição, e não tal lei ordinária deve governar o caso ao qual ambas se aplicam. Aqueles, portanto, que controvertem o princípio de que a Constituição deve ser considerada na Corte, como um Direito supremo, são levados à necessidade de provar o fato de que os tribunais devem fechar seus olhos sobre a Constituição e ver apenas a lei. Essa doutrina subvertia o próprio fundamento de todas as constituições escritas. Ela declararia que uma lei que, segundo os princípios e a teoria de nosso Governo for inteiramente nula, seria ainda, na prática, perfeitamente obrigatória. Declararia que, se o Legislativo fizer o que é expressamente proibido, tal ato, todavia, apesar da proibição, será em verdade válido. Estaria dando ao Legislativo uma onipotência prática e real, com o mesmo alento com que professa a restrição de seus poderes dentro de limites escritos. É prescrever limites e declarar que aqueles limites podem ser ultrapassados por prazer. Que ela, pois, reduz ao nada o que temos considerado como de maior aperfeiçoamento em instituições políticas, uma Constituição escrita, seria por si só suficiente, na América, onde as constituições escritas têm sido olhadas com tanta reverência, para rejeitar a construção. 
Após inúmeras importantes observações, o CHIEF JUSTICE MARSHALL concluiu que estava terminantemente proibido ao Poder Legislativo ampliar, por meio de legislação ordinária, as competências originárias da CORTE SUPREMA, em face de sua previsão taxativa no texto constitucional; consequentemente, apesar de a SUPREMA CORTE ter entendido ser ilegal a conduta do Secretário de Estado Madison, entendeu, preliminar e prejudicialmente, que carecia de competência para emitir o mandado requerido, uma vez que as competências da Suprema Corte estariam taxativamente previstas pela Constituição, não podendo o Congresso Nacional, por meio da Lei Judiciária de 1789, ampliá-las.

Esse posicionamento - previsão constitucional taxativa das competências originárias da CORTE SUPREMA - tem mais de 200 anos no Direito Constitucional norte-americano e mais de 115 anos na doutrina e jurisprudência nacionais, pois, igualmente, foi consagrado no Brasil desde nossos primeiros passos republicanos (RTJ 43/129, RTJ 44/563, RTJ 50/72, RTJ 53/776), uma vez que o SUPREMO TRIBUNAL FEDERAL, que nasceu republicano com a Constituição de 1891 e com a função precípua de defender a Constituição em face, principalmente, do Poder Legislativo, por meio da revisão da constitucionalidade das leis, jamais admitiu que o Congresso Nacional pudesse alterar suas competências originárias por legislação ordinária (AFONSO ARINOS. Curso de direito constitucional brasileiro. Rio de Janeiro: Forense, 1960. p. 98), pois, como salientado por nossa CORTE SUPREMA, seu "complexo de atribuições jurisdicionais de extração essencialmente constitucional, não comporta a possibilidade de extensão, que extravasem os rígidos limites fixados em numerus clausus pelo rol exaustivo inscrito no art. 102, I, da Carta Política" (STF - Petição no 1.026-4/DF - Rel. MINISTRO CELSO DE MELLO, Diário da Justiça, Seção I, 31 maio 1995, p. 15855. No mesmo sentido: RTJ 43/129; RTJ 44/563; RTJ 50/72; RTJ 53/776).

No exercício de suas competências originárias, que extravasam as tradicionais competências de TRIBUNAIS ou CORTES CONSTITUCIONAIS, o SUPREMO TRIBUNAL FEDERAL analisará a questão em única instância, desde que haja expressa e taxativa previsão constitucional; devendo processar e julgar originariamente os casos em que os Direitos Fundamentais das mais altas autoridades da República estiverem sob ameaça ou concreta violação, ou quando essas autoridades estiverem violando direitos fundamentais dos indivíduos, entre eles (CF, art. 102, I, "b" e "c")

O SUPREMO TRIBUNAL FEDERAL possui, portanto, a seguinte competência penal originária: 
Art. 102. Compete ao Supremo Tribunal Federal, precipuamente, a guarda da Constituição, cabendo-lhe:

I - processar e julgar, originariamente:

(...)

b) nas infrações penais comuns, o Presidente da República, o VicePresidente da República, os membros do Congresso Nacional, seus próprios Ministros e o Procurador-Geral da República;

c) nas infrações penais comuns e nos crimes de responsabilidade, os Ministros de Estado e os Comandantes da Marinha, do Exército e da Aeronáutica, ressalvado o disposto no artigo 52, I, os membros dos Tribunais Superiores, os do Tribunal de Contas da União e os chefes de missão diplomática de caráter permanente.

As autoridades descritas no artigo 102, I, "b" e "c" da Carta Magna somente poderão ser processadas e julgadas, nas infrações penais comuns, pelo SUPREMO TRIBUNAL FEDERAL.

A abrangência desta prerrogativa constitucional de foro das mais altas autoridades da República relaciona-se com a locução "crimes comuns", prevista no art. 53, §4º e art. 102, inciso I, b, ambos da Constituição Federal, cuja definição o SUPREMO TRIBUNAL FEDERAL — há muito tempo (RTJ 33/590, HC 69.344-RJ, Rel. MINISTRO NÉRI DA SILVEIRA; RTJ 63/1, Pet. 673-RJ, Rel. MINISTRO CELSO DE MELLO; Inq. 496-DF, Rel. MINISTRO ILMAR GALVÃO; RTJ 91/423, Reclamação no 511-9-Paraíba, Rel. MINISTRO CELSO DE MELLO, Diário da Justiça no 202, 24 out. 1994, p. 28.668) - já determinou abranger todas as modalidades de infrações penais estendendo-se aos delitos eleitorais, alcançando, até mesmo, os crimes contra a vida e as próprias contravenções penais.

A definição de competência em relação à prerrogativa de foro em razão da função rege-se, porém, pela regra da atualidade do cargo/mandato, ou seja, tratando-se de crime comum praticado por detentores de foro privilegiado na vigência do cargo/mandato, seja ou não relacionado com o exercício das funções, enquanto durar o cargo/mandato, a competência será do SUPREMO TRIBUNAL FEDERAL.

Encerrado o exercício do cargo/mandato e, consequentemente, cessada a prerrogativa de foro, não mais subsistirá a competência de nossa CORTE SUPREMA para o processo e julgamento, uma vez que o próprio TRIBUNAL, por unanimidade, cancelou sua Súmula no 394 ("Cometido o crime durante o exercício funcional, prevalece a competência especial por prerrogativa de 
função, ainda que o inquérito ou a ação penal sejam iniciados após a cessação daquele exercício.") por entender que:

o art. 102, I, b, da CF - que estabelece a competência do STF para processar e julgar originariamente, nas infrações penais comuns, $\mathrm{O}$ Presidente da República, o Vice-Presidente, os membros do Congresso Nacional, seus próprios Ministros e o Procurador-Geral da República - não alcança aquelas pessoas que não mais exerçam mandato ou cargo" (STF - Pleno - Inquérito no 687/SP - questão de ordem Rel. Min. Sydney Sanches; STF - Pleno - Inquérito nº 881/MT questão de ordem - Rel. Min. Sydney Sanches; STF - Pleno - Ações Penais nos 313/DF, 315/DF, 319/DF, 656/AC - questão de ordem - Rel. Moreira Alves, 25-8-1999 - todos no Informativo STF no 159. Conferir, ainda, nesse mesmo sentido: STF - Inquérito no 1.461-3/AL - Rel. Min. Sepúlveda Pertence, Diário da Justiça, Seção I, 8 set. 1999, p. 24; STF - Pleno - Ação Penal no 313-8/DF - questão de ordem - Rel. Min. Moreira Alves, Diário da Justiça, Seção I, 9 set. 1999, capa; STF - Pleno - Ação Penal no 315-4/DF - questão de ordem - Rel. Min. Moreira Alves, Diário da Justiça, Seção I, 9 set. 1999, p. 2; STF - Pleno - Ação Penal no 319-7/DF - questão de ordem - Rel. Min. Moreira Alves, Diário da Justiça, Seção I, 9 set. 1999, p. 2; STF - Inquérito no 656-4/AC - questão de ordem - Rel. Min. Moreira Alves, Diário da Justiça, Seção I, 9 set. 1999, p. 2; STF - Inquérito no 881-8/MT - questão de ordem - Rel. Min. Moreira Alves, Diário da Justiça, Seção I, 9 set. 1999, p. 2).

O SUPREMO TRIBUNAL FEDERAL decidiu que não mais ocorreria a perpetuação de sua competência para o processo e julgamento dos crimes comuns praticados pelas autoridades previstas no art. 102, I, $b$ e $c$, quando cessarem seus mandatos/cargos, deixando de ser aplicação a regra da contemporaneidade da infração penal comum com o exercício do mandato/ cargo e, consequentemente, os autos passaram a ser remetidos à Justiça de $1^{\circ}$ grau (Nesse sentido, conferir: STF - Inquérito no 2.252-7/DF - Rel. Min. CELSO DE MELLO, Diário da Justiça, Seção I, 25 maio 2006, p. 8; STF Inquérito no 2.277/DF - questão de ordem - Rel. Min. MARCO AURÉLIO, decisão: 24-5-2006, Informativo STF no 428).

As razões que levaram a SUPREMA CORTE ao cancelamento da Súmula 394 foram trazidas no voto condutor do MINISTRO RELATOR SYDNEY SANCHES, que expôs, ao analisar os efeitos da referida Súmula: 
Mas não se pode negar, por outro lado, que são eles trabalhosíssimos, exigindo dos Relatores que atuem como verdadeiros Juízes de $1^{\circ}$ grau, à busca de uma instrução que propicie as garantias que justificaram a Súmula 394. Penso que, a esta altura, se deva chegar a uma solução oposta a ela, ao menos como um primeiro passo da Corte para se aliviar das competências não expressas na Constituição, mas que ela própria se atribuiu, ao interpretá-la ampliativamente e, às vezes, até, generosamente, sem paralelo no Direito comparado. Se não se chegar a esse entendimento, dia virá em que o Tribunal não terá condições de cuidar das competências explícitas, com o mínimo de eficiência, de eficácia e de celeridade, que se deve exigir das decisões de uma Suprema Corte. Os riscos, para a Nação, disso decorrentes, não podem ser subestimados e, a meu ver, hão de ser elevados em grande conta, no presente julgamento. (Trecho do voto do Ministro SYDNEY SANCHES, na questão de ordem do Inquérito no 687/SP - Informativo STF no 159)

Dessa forma, não mais foi admitida a perpetuação da competência do SUPREMO TRIBUNAL FEDERAL para o processo e julgamento dos crimes comuns praticados pelas autoridades previstas no art. 102, I, " $b$ " $\mathrm{e}$ " $c$ ", quando cessarem seus cargos/mandatos.

O Congresso Nacional, ignorando a interpretação dada ao artigo 102, I, "b" e "c", da Constituição Federal pelo SUPREMO TRIBUNAL FEDERAL, editou a Lei no 10.628 , de 24 de dezembro de 2002, alterando a redação do

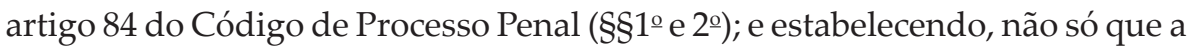
ação de improbidade deveria ser proposta perante o tribunal competente para processar e julgar criminalmente o funcionário ou autoridade na hipótese de prerrogativa de foro em razão do exercício de função pública; mas também que essa competência especial por prerrogativa de função, tanto penal quanto por improbidade administrativa, deveria prevalecer ainda que o inquérito ou a ação se iniciassem após a cessação do exercício da função pública ( $\$ 2$ 으, do art. 84 do (PP), revigorando a antiga regra da contemporaneidade fato/ mandato prevista na Súmula 394 do STF.

Essa extensão de competência ao SUPREMO TRIBUNAL FEDERAL para o processo ejulgamento de ações penais e ações de improbidade administrativa feriu frontalmente a definição taxativa de competências da CORTE SUPREMA prevista no artigo 102, I, b da Constituição Federal, usurpando sua função de "guardião e intérprete da Constituição" e, consequentemente, foi declarada 
inconstitucional (STF - Pleno - Adin no 2797/DF e Adin no 2860/DF, Rel. Min. SEPÚLVEDA PERTENCE, decisão: 15-9-2005 - Informativo STF no 401, p. 1), pois como afirmou em relação à SUPREMA CORTE AMERICANA, o JUDGE HUGHES (Charles E. Hughes foi nomeado para a Suprema Corte americana em 1910, pelo Presidente William H. Taft, tendo exercido seu mister até o ano de 1916), "a Constituição é o que o juiz diz que ela é".

O SUPREMO TRIBUNAL FEDERAL, portanto, declarou inconstitucional a Lei no $10.628 / 02$, em relação ao $§ 1^{\circ}$ o do artigo 84 do Código de Processo Penal, tendo sido ressaltado pelo MINISTRO-RELATOR SEPÚLVEDA PERTENCE,

por considerar que o mesmo, além de ter feito interpretação autêntica da Carta Magna, o que seria reservado à norma de hierarquia constitucional, teria usurpado a competência do STF como guardião da Constituição Federal ao inverter a leitura por ele já feita de norma constitucional, o que, se admitido, implicaria sujeitar a interpretação constitucional do STF ao referendo do legislador ordinário. (STF - Pleno - Adin no 2797/DF e Adin no 2860/DF, Rel. MINISTRO SEPÚLVEDA PERTENCE, decisão: 15-9-2005 - Informativo STF no 401, p. 1)

Igualmente, a nova regra trazida pela Lei $\mathrm{n}^{\circ} \mathbf{1 0 . 6 2 8}$, de 24 de dezembro de 2002, ao estabelecer no $\S 1^{\circ}$, do art. 84 do CPP, que a ação de improbidade administrativa deveria ser proposta perante o tribunal competente para processar e julgar criminalmente o funcionário ou autoridade na hipótese de prerrogativa de foro em razão do exercício de função pública; estava, em relação ao SUPREMO TRIBUNAL FEDERAL, estendendo o foro privilegiado penal previsto no art. 102, I, "b" e " $c$ " da Constituição Federal, também para as hipóteses de prática de atos de improbidade administrativa; ampliando, por lei ordinária, as competências originárias da CORTE.

Nos termos da nova regulamentação, o SUPREMO TRIBUNAL FEDERAL passaria a ser competente para o processo e julgamento das ações de improbidade administrativa praticadas por todos os detentores de foro penal privilegiado, em clara extensão do alcance do artigo 102, I, "b" e "c" da Carta Magna.

Ocorre, porém, que o SUPREMO TRIBUNAL FEDERAL, interpretando suas competências originárias previstas no art. 102, já havia estabelecido que somente pudesse processar e julgar, originariamente, as hipóteses previstas no texto constitucional, e entre elas não se encontrava a hipótese de improbidade administrativa de altas autoridades da República, ou ainda, o julgamento da 
ação popular de Parlamentares, Ministros de Estado ou do próprio Presidente da República, por não estarem na esfera das atribuições jurisdicionais originárias de nossa CORTE SUPREMA (Pet. 296-2, Rel. Min. CÉLIO BORJA, DJU, de 10 nov. 1988; Pet. 352-7, Rel. Min. SYDNEY SANCHES, DJU, de 9 jun. 1989; Pet. 431-1, Rel. Min. NÉRI DA SILVEIRA, DJU, de 10 ago. 1990; Pet 487-6, Rel. Min. MARCO AURÉLIO, DJU, de 20 jun. 91; Pet. 682-MS, Rel. Min. CELSO DE MELLO, DJU, de 9 fev. 1993; Informativo STF no 73 Pet. 1282-RJ, Rel. SYDNEY SANCHES; Pet. 129-0, Rel. Min. MOREIRA ALVES, DJU, de 25 fev. 1985).

Assim, apesar de a Constituição Federal prever a competência originária do SUPREMO TRIBUNAL FEDERAL para os feitos criminais e mandados de segurança em relação às diversas autoridades, em relação às demais ações propostas, inclusive ações civis públicas (STF - Pleno - Agravo regimental em petição no 693-4/SP - Rel. Min. ILMAR GALVÃO) e ações por ato de improbidade, carecia o PRETÓRIO EXCELSO de competência, por falta de previsão específica do rol taxativo do art. 102 da Carta Magna, como destacado pela CORTE:

como a alegação de improbidade administrativa concerne à atuação do acusado como Prefeito Municipal, observadas as formalidades legais atinentes à espécie, competente para propor a ação de improbidade administrativa é o Representante do Ministério Público Estadual, com atribuição específica, ou a Prefeitura de Acaraú (art. 17 da Lei 8.429). Obviamente, o Supremo Tribunal Federal não é o órgão competente para conhecer, inicialmente, de ação de improbidade administrativa, ainda que proposta contra quem detenha atualmente o mandato de Deputado Federal. (STF - Inquérito nำ1202-5/CE - Rel. Min. CARLOS VELLOSO, Diário da Justiça, Seção I, 4 mar. 1997, p. 4.800)

Em face disso, foi, igualmente, declarada a inconstitucionalidade em relação ao $\S 2$ 을 do art. 84 do CPP, entendendo o SUPREMO TRIBUNAL FEDERAL que:

esse parágrafo veiculou duas regras: a que estende a competência especial por prerrogativa de função para inquérito e ação penais à ação de improbidade administrativa e a que manda aplicar, em relação à mesma ação de improbidade, a previsão do $§ 1^{\circ}$ do citado artigo. Esta 
última regra, segundo o relator, estaria atingida por arrastamento pela declaração de inconstitucionalidade já proferida. E a primeira implicaria declaração de competência originária não prevista no rol taxativo da Constituição Federal. Ressaltou que a ação de improbidade administrativa é de natureza civil, conforme se depreende do $\S 4^{\circ}$ do art. 37 da CF e que o STF jamais entendeu ser competente para o conhecimento de ações civis, por ato de ofício, ajuizadas contra as autoridades para cujo processo penal o seria. (STF - Pleno - Adin no 2797/DF e Adin no 2860/DF, Rel. MINISTRO SEPÚLVEDA PERTENCE, decisão: 15-9-2005 - Informativo STF no 401, p. 1).

Em relação à incompetência do SUPREMO TRIBUNAL FEDERAL para o processo e julgamento de ações populares contra os detentores de foro penal privilegiado, nossa CORTE reiterou seu clássico posicionamento, após a declaração de inconstitucionalidade da Lei no 10.628/2002 (STF - Pets. nºs 3.033-8/SP, 3.047-8/DF, 3.278-1/MA, 3.337-0/SC - Rel. Min. CELSO DE MELLO, Diário da Justiça, Seção I, 6 out. 2005, p. 13 e 14; STF - Recls. no ${ }^{\text {os }}$ 2.2277/DF, 2.746-5/SC, 2.766-0/RN, 2.870-4/MG - Rel. Min. CELSO DE MELLO, Diário da Justiça, Seção I, 3 out. 2005, p. 9 e 10).

Eventuais alterações dessas regras, prevendo competência originária do Supremo Tribunal Federal para processo e julgamento de ações de improbidade administrativa, bem como prorrogação da prerrogativa de foro após o final do cargo/mandato, seja no cível, seja no crime, somente poderão ocorrer com expressa alteração constitucional, por meio de Emendas à Constituição, uma vez que o próprio PRETÓRIO EXCELSO somente admite, e ainda, excepcionalmente, a alteração de suas competências originárias pelo legislador constituinte derivado (a respeito dessa possibilidade, conferir análise pelo STF da EC no 22/99, que transferiu o processo e julgamento de habeas corpus contra ato de coação derivado de decisão colegiado de TRF ou Tribunais Estaduais do Supremo Tribunal Federal para o Superior Tribunal de Justiça (STF - 2a T. - HC no 78.416/RJ - questão de ordem - Rel. Min. MAURÍCIO CORRÊA, decisão: 22-3-1999; STF - 1aㅜ T. - HC no 78.756-6/SP - Rel. Min. SEPÚLVEDA PERTENCE, Diário da Justiça, Seção I, 29 de março 1999, p. 21), sendo absolutamente vedado ao legislador ordinário ampliar as suas competências originárias.

Parece-nos que o próprio Congresso Nacional verificou essa obrigatoriedade, pois, demonstrando a necessidade de alteração constitucional, o Senado Federal aprovou o Parecer no 1.748 , e, posteriormente, em dois turnos, 
a Proposta de Emenda à Constituição no 29, de 2000 (no 96, de 1999, na Câmara dos Deputados), constante da Emenda no 240, da Comissão de Constituição, Justiça e Cidadania, enviando o texto à Câmara dos Deputados, para nova análise e eventual aprovação em dois turnos, pelo quórum qualificado de 3/5. No texto aprovado, estende-se o mesmo foro criminal especial por prerrogativa de função, previsto constitucionalmente às diversas autoridades, às ações de improbidade administrativa (criação do art. 97-A).

\section{(II) Excepcionalidade e taxatividade das competências originárias do Supremo Tribunal Federal - impossibilidade de ampliação pela aplicação da teoria dos poderes implícitos}

As competências originárias do SUPREMO TRIBUNAL FEDERAL são expressas e taxativamente previstas pela Constituição Federal, não se admitindo ampliação pelo legislador ordinário, nem tampouco com base em supostas competências originárias implícitas.

Observe-se que inexistem competências originárias implícitas no texto constitucional, tendo sido fixado desde logo, em relação às competências originárias da CORTE SUPREMA AMERICANA, assim como do SUPREMO TRIBUNAL FEDERAL, não ser possível a aplicação da Teoria dos Poderes Implícitos, também criada pela CORTE AMERICANA, pois se encontram em rol taxativamente descrito no texto constitucional, diversamente do que ocorreu com o artigo II da Constituição norte-americana, que, ao prever os poderes e funções presidenciais, foi a norma mais indefinida do texto, deixando de estabelecer todos os poderes presidenciais de antemão, permitindo, assim, como salientado por Edward Corwin, maior liberdade para o jogo de forças políticas (El poder ejecutivo. Buenos Aires: Editorial Bibliográfica Argentina, 1959. p. 42 ss.).

A análise dos poderes presidenciais tem início na interpretação do artigo II, $\S 1$ o, ao prever que o "Poder Executivo deve ser investido no Presidente dos Estados Unidos da América".

A Convenção Constitucional norte-americana estipulou genericamente que a competência mais importante do Presidente da República é sua responsabilidade de impor a lei. 
A própria Constituição de 1787 previu ao Chefe do Executivo a obrigação de "cuidar para que as leis sejam fielmente executadas", delegando ao Presidente a responsabilidade de forçar o cumprimento das leis dos Estados Unidos (HENRY LEARNED. The president's cabinet: studies in the origin, formation and structure of an American institution. New Haven: Yale University Press, 1912. p. 380).

Para tanto, na história do presidencialismo, o Congresso Nacional americano vem, historicamente, como apontado por Thomas Cooley, adicionando poderes por meio de medidas que capacitam o Chefe do Executivo a agir rápida e vigorosamente (The general principles of constitutional law in the United States of America. 3. ed. Boston: Little, Brown and Company, 1898. p. 121).

Essa autoridade do Presidente como chefe oficial de imposição das leis dos Estados Unidos foi ainda mais efetivada por decisões da Corte Suprema, que apesar de apontar a ausência de lei específica que autorizasse o Presidente a nomear o Procurador-geral, como garantidor maior da aplicação da lei, entendeu que esse poder era decorrente da função presidencial de exigir e garantir o fiel cumprimento da legislação norte-americana (ERNEST BARKSDALE FINCHER. The president of the United States. New York: AbelardSchuman, 1955. p. 72 ss.), pois, como ressaltado por Wilson Woodrow,

no aspecto Constitucional de executivo legal não se pode supor isolado o Presidente. Não pode ele executar leis. A execução quotidiana delas há de competir aos diversos departamentos executivos e ao numeroso corpo de funcionários federais espalhados em todo o país, no que diz respeito aos deveres estritamente executivos do seu cargo, pode-se dizer que o Presidente administra a presidência conjuntamente com os membros do gabinete, como o presidente de uma comissão. (O presidente dos Estados Unidos. Rio de Janeiro: Jacintho Ribeiro dos Santos Editor, 1917. p. 23)

Após isso, com base na análise da decisão da Corte Suprema americana no caso Myers v. Estados Unidos (US 272 - 52, 118), envolvendo o Diretor dos Correios de Oregon (1926), a enumeração do artigo II foi interpretada com a finalidade de trazer um novo caminho para uma completa revolução no sistema presidencial americano, ao possibilitar a conversão do governo nacional, de governo de atribuições taxativas, em governo de atribuições genericamente previstas no texto constitucional, estabelecendo o Poder Executivo 
como essencial no governo e conferindo ao Presidente da República poderes mais amplos.

Como salientado por Pedro Carlos Bacelar de Vasconcelos (A separação dos poderes na constituição americana. Coimbra: Coimbra Editora, 1994. p. 28),

a não referência da outorga do Poder Executivo a um elenco específico de competências, ao contrário do que se passa com o Congresso, foi interpretada por Alexander Hamilton no sentido da não restrição do Executivo às atribuições explícitas, segundo ele incidentais, das seções 2 e 3 do art. II. Estaríamos antes perante o reconhecimento de uma competência genérica de poderes implícitos - inherent powers - do Executivo, apenas sujeitos às proibições e limites estruturais da Constituição. Esta tese mantém atualidade e foi sobretudo influente no domínio das relações externas.

Nessa decisão, a CORTE SUPREMA aceitou a ideia original dos federalistas, defendida diretamente por Hamilton, e concluiu que o Chefe do Poder Executivo Federal poderia exercitar o poder originário de fontes não enumeradas, contanto que não proibidas pelo texto constitucional, diversamente do que ocorre no âmbito da distribuição de competências legislativas e das competências originárias da própria Corte, tendo afirmado o Tribunal que "o Poder Executivo foi concedido em termos gerais, fortalecido por termos específicos onde a ênfase foi considerada apropriada, e foi limitado por expressões diretas onde a limitação foi necessária".

O poder do Presidente de obrigar e garantir o cumprimento da lei do país, de administrar ou de conduzir os negócios do governo, e de nomear e demitir seus assessores diretos, responsáveis por cumprir suas ordens, deriva diretamente da previsão constitucional que lhe garante a autoridade executiva (ERNEST BARKSDALE FINCHER. The president of the United States. New York: Abelard-Schuman, 1955. p. 87).

Autorizou-se, portanto, a possibilidade de aplicação para o Órgão Executivo da Teoria dos Poderes Implícitos - inherent powers - , pela qual no exercício de sua missão constitucional enumerada, o órgão executivo deveria dispor de todas as funções necessárias, ainda que implícitas, desde que não expressamente limitadas (Myers v. Estados Unidos - US 272 - 52, 118), consagrando-se, dessa forma, o reconhecimento de competências executivas genéricas e implícitas que possibilitem o exercício de sua missão constitucional, apenas sujeitas às proibições e limites estruturais da Constituição Federal. 
Em relação às competências originárias da CORTE SUPREMA não será possível a utilização da Teoria dos Poderes Implícitos, pois o texto constitucional expressa e taxativamente estabelece um rol específico de competências originárias.

Conforme analisado anteriormente, em Marbury v. Madison (1 Cranch 137 - 1803), o CHIEF JUSTICE MARSHALL, após afirmar que “a Constituição é um chefe superior, do Direito, imutável por meios ordinários, ou estará num mesmo nível com as leis ordinárias e, como as outras, poderá ser alterada quando o Legislativo quiser", e que, "certamente, todos os que têm fundado Constituições escritas contemplam-nas como formadoras do Direito fundamental e supremo da Nação, consequentemente, abraçam a teoria de que cada governo deve aceitar que uma lei ordinária em conflito com a Constituição é inoperante", concluiu que estava terminantemente proibido ao Poder Legislativo ampliar, por meio de legislação ordinária, as competências originárias da CORTE SUPREMA, em face de sua previsão taxativa no texto constitucional.

A mesma conclusão é inteiramente aplicável ao SUPREMO TRIBUNAL FEDERAL, cujo rol de competências originárias é expresso e taxativamente previsto no texto de nossa CARTA MAGNA, sendo pacífico o posicionamento do SUPREMO TRIBUNAL FEDERAL sobre a impossibilidade de ampliação do rol taxativo de suas competências constitucionais originárias por LEGISLAÇÃO ORDINÁRIA bem como não sendo possível a aplicação da TEORIA DOS PODERES IMPLÍCITOS - "inherent powers".

\section{(III) Excepcionalidade e taxatividade das competências originárias do Supremo Tribunal Federal - impossibilidade de ampliação indireta e reflexa pela aplicação de regras previstas na legislação ordinária (conexão e continência) - inaplicabilidade da Súmula 704}

Tendo o SUPREMO TRIBUNAL FEDERAL pacificado a impossibilidade de ampliação do rol expresso e taxativo de suas competências constitucionais originárias por legislação ordinária, não guarda lógica e razoabilidade, a possibilidade de se permitir essa ampliação por aplicação interpretativa de 
lei ordinária já existente, ou seja, NÃO SE PODE EDITAR, MAS SE PODE APROVEITAR LEI JÁ EDITADA.

Dessa forma, não encontra respaldo no PRINCÍPIO DA RAZOABILIDADE qualquer interpretação da legislação ordinária, que, visando garantir maior alcance a institutos infraconstitucionais (como na espécie, conexão e continência), acabe por permitir, que, de maneira reflexa, o rol taxativo de autoridades submetidas à competência penal originária da CORTE SUPREMA possa ser ampliado sem qualquer limitação por simples lei ordinária.

O PRINCÍPIO DA RAZOABILIDADE pode ser definido como aquele que exige Proporcionalidade, Justiça e Adequação entre os meios utilizados pelo Poder Público, no exercício de suas atividades - na hipótese, ATIVIDADE JURISDICIONAL - , e os fins por ela almejados, levando-se em conta critérios racionais e coerentes (cf. MARIA PAULA DALLARI BUCCI. O princípio da razoabilidade em apoio à legalidade. Cadernos de Direito Constitucional e Ciência Política. RT, São Paulo, ano 4, no 16, p. 173, jul./set. 1996; CELSO ANTÔNIO BANDEIRA DE MELLO. Regulamentação profissional: princípio da razoabilidade. Revista de Direito Administrativo. v. 204, p. 333 ss., abr./jun. 1996).

Conforme destacado por JOSÉ EDUARDO MARTINS CARDOSO (Princípios constitucionais da administração pública (de acordo com a emenda constitucional no 19/98, in Os 10 anos da Constituição Federal. São Paulo: Atlas, 1998, p. 182), sob a óptica da Administração Pública, o PRINCÍPIO DA RAZOABILIDADE pode ser definido como o princípio que determina aos Poderes Públicos "o dever de atuar em plena conformidade com critérios racionais, sensatos e coerentes, fundamentados nas concepções sociais dominantes".

$O$ que se espera do SUPREMO TRIBUNAL FEDERAL, na presente hipótese, é uma COERÊNCIA LÓGICA entre O PACÍFICO POSICIONAMENTO SECULAR DA IMPOSSIBILIDADE DE AMPLIAÇÃO DE SUAS COMPETÊNCIAS ORIGINÁRIAS POR LEGISLAÇÃO ORDINÁRIA e A IMPOSSIBILIDADE DE APLICAÇÃO DAS REGRAS DO CÓDIGO DE PROCESSO PENAL (CONEXÃO E CONTINÊNCIA) AO ARTIGO 102, I, “b” $\mathrm{e}$ "c" DA CONSTITUIÇÃO FEDERAL (FORO PRIVILEGIADO), pois como apontado por AUGUSTIN GORDILLO (Princípios gerais do direito público. São Paulo: RT, 1977. p. 183), a decisão do Poder Público será sempre ilegítima, desde que sem racionalidade, mesmo que não transgrida explicitamente norma concreta e expressa, ou ainda, no dizer de ROBERTO DROMI (Derecho administrativo. 6. ed. Buenos Aires: Ciudad Argentina, 1997. p. 36), a razoabilidade engloba a prudência, a proporção, a indiscriminação, a proteção, a proporcionalidade, a causalidade, em suma, a não arbitrariedade. 
Como apontar racionalidade, proporção e causalidade entre entendimentos tão díspares, que em um primeiro momento NÃO PERMITE que seja editada legislação ordinária que, expressa e diretamente, amplie as competências originárias do SUPREMO TRIBUNAL FEDERAL; porém, em um segundo momento, acaba por PERMITIR que implícita e reflexamente legislação ordinária já existente acabe por ampliar as citadas competências originárias?

Não é prudente, protetivo e não abusivo esse entendimento contraditório, pois acaba por conceder ao Poder Legislativo enorme discricionariedade para reflexamente dispor sobre as competências originárias do SUPREMO TRIBUNAL FEDERAL, como melhor lhe aprouver, bastando para tanto que amplie as hipóteses legais de conexão e continência, mesmo que de maneira inadequada e excessiva.

Tanto a edição de legislação ordinária que expressa e diretamente amplie as competências originárias de nossa CORTE SUPREMA, quanto a aplicação de legislação ordinária já existente que implícita e reflexamente acabe por ampliá-la são inconstitucionais.

ARAZOABILIDADE, portanto, deve ser utilizada como parâmetro para se evitarem os tratamentos excessivos (ubermassig), inadequados (unangemessen), buscando-se sempre no caso concreto o tratamento necessariamente exigível (erforderlich, unerlablich, undedingt notwendig).

Na presente hipótese, portanto, o tratamento exigível, adequado e não excessivo exige a integral aplicação do entendimento pacífico do SUPREMO TRIBUNAL FEDERAL pela inconstitucionalidade da ampliação de suas competências originárias por lei ordinária, também em relação às normas ordinárias já existentes.

A taxatividade do rol de competências constitucionais originárias do SUPREMO TRIBUNAL FEDERAL é absoluta, não havendo possibilidades de ampliação direta e expressa por meio de edição de lei ordinária, ou mesmo, indireta e reflexa, pela aplicação da Teoria dos Poderes Implícitos ou interpretação de lei ordinária já existente.

Sob essa exegese deve ser analisada a impossibilidade da aplicação das regras legais de conexão e continência previstas no Código de Processo Penal à previsão de foro privilegiado (CF, art. 102, I, " $b$ " e "c"), uma vez que estaríamos de forma inconstitucional ampliando as competências originárias do SUPREMO TRIBUNAL FEDERAL.

Em que pese a decisão proferida em questão de ordem, nos autos do Inquérito 2245-QO/MG, em 6 de dezembro de 2006, onde, por maioria de 
votos, decidiu o Plenário do SUPREMO TRIBUNAL FEDERAL pelo não desmembramento do inquérito policial, é importante ressaltar que sua fundamentação foi baseada na questão de adoção do critério subjetivo ou objetivo previsto no artigo 80 do Código de Processo Penal, como se verifica em sua Ementa:

QUESTÃO DE ORDEM. INQUÉRITO. DESMEMBRAMENTO. ARTIGO 80 DO CPP. CRITÉRIO SUBJETIVO AFASTADO. CRITÉRIO OBJETIVO. INADEQUAÇÃO AO CASO CONCRETO. MANUTENÇÃO INTEGRAL DO INQUÉRITO SOB JULGAMENTO DA CORTE. Rejeitada a proposta de adoção do critério subjetivo para o desmembramento do inquérito, nos termos do artigo 80 do CPP, resta o critério objetivo, que, por sua vez, é desprovido de utilidade no caso concreto, em face da complexidade do feito. Inquérito não desmembrado. Questão de ordem resolvida no sentido da permanência, sob a jurisdição do Supremo Tribunal Federal, de todas as pessoas denunciadas.

Posteriormente, no momento do recebimento da Denúncia, em sessão realizada pelo Plenário em 28 de agosto de 2007, o SUPREMO TRIBUNAL FEDERAL, em preliminar, decidiu que:

PRIMEIRA PRELIMINAR. INCOMPETENNCIA. FORO POR PRERROGATIVA DE FUNÇÃO. DESEMEMBRAMENTO. INDEFERIDO PELO PLENO. PRECLUSÃO. Rejeitada a preliminar de incompetência do STF para julgar a acusação formulada contra os 34 (trinta e quatro) acusados que não gozam de prerrogativa de foro. Matéria preclusa, tendo em vista que na sessão plenária realizada no dia 06/12/06 decidiuse, por votação majoritária, pela necessidade de manter-se um processo único, a tramitar perante o Supremo Tribunal Federal.

Ocorre, porém, que tanto na sessão Plenária do dia 6 de dezembro de 2006, quanto na sessão Plenária de 28 de agosto de 2007, o SUPREMO TRIBUNAL FEDERAL analisou juridicamente a questão sob a ótica do Direito Processual Penal, ou seja, aplicação dos critérios subjetivo ou objetivo ao caso concreto, não tendo ocorrido análise frontal da questão sob o ângulo Constitucional, ou seja, sobre a inconstitucionalidade de ampliação das competências constitucionais da CORTE SUPREMA por norma legal (conexão e continência). 
A necessidade de análise, pelo PLENÁRIO DA CORTE, da inconstitucionalidade de ampliação das competências constitucionais da CORTE SUPREMA por norma legal (conexão e continência) se torna imprescindível quando vários pronunciamentos posteriores da CORTE demonstram que 8 (oito) dos atuais Ministros (MINISTROS CELSO DE MELLO, MARCO AURÉLIO, GILMAR MENDES, CEZAR PELUSO, CARLOS BRITTO, JOAQUIM BARBOSA, RICARDO LEWANDOWISKI e CARMEM LÚCIA) já se manifestaram, EM DECISÕES POSTERIORES À QUESTÃO DE ORDEM DO INQUÉRITO 2245-QO/MG, pelo desmembramento de inquérito, em casos semelhantes, em face da taxatividade constitucional das competências originárias do STF e os 2 (dois) outros Ministros (MINISTROS DIAS TÓFFOLI e LUIZ FUX) ainda não tiveram possibilidade de se manifestar sobre o assunto, conforme verificamos abaixo.

Em 20 de junho de 2007, por unanimidade, o Plenário da CORTE SUPREMA entendeu não ser possível o remembramento de inquérito policial, afirmando que:

INQUÉRITO - REMEMBRAMENTO - ACUSADOS SEM PRERROGATIVA DE FORO - CONEXÃO - CONTINÊNCIA - SUPREMO. Não concorre a indispensável relevância da causa de pedir do remembramento de inquérito, presente a competência do Supremo definida na Constituição Federal, considerada a disciplina legal da conexão e da continência.

Participaram do julgamento oito dos atuais membros do Supremo Tribunal Federal: MINISTROS MARCO AURÉLIO, ELLEN GRACIE (Presidente), SEPÚLVEDA PERTENCE, CELSO DE MELLO, GILMAR MENDES, CEZAR PELUSO, CARLOS BRITTO, JOAQUIM BARBOSA, EROS GRAU, RICARDO LEWANDOWISKI e CARMEM LÚCIA.

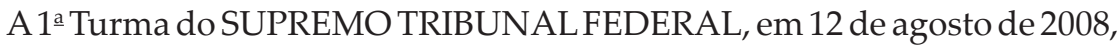
proclamou a impossibilidade de ampliação do rol taxativo de competências constitucionais originárias da Corte por aplicação da legislação ordinária, em especial, das regras de conexão e continência, proclamando:

COMPETÊNCIA - PRERROGATIVA DE FORO - NATUREZA DA DISCIPLINA. A competência por prerrogativa de foro é de Direito estrito, não se podendo, considerada conexão ou continência, estendê-la a 
ponto de alcançar o inquérito ou ação penal relativos a cidadão comum. (STF, 1aㅡ., Rel. Min. MARCO AURÉLIO, DJe-187, publicado em 3 de outubro de 2008).

Importante destacar que o MINISTRO RELATOR MARCO AURÉLIO afirmou em seu voto que:

Não abro exceção, já disse inclusive em Plenário. Não posso conceber que uma norma instrumental comum alusiva à continência e à conexão modifique a situação, altere a Carta da República, tão mal amada, quanto à competência do Tribunal, seja do Superior Tribunal ou do Supremo. Por isso é que estou, agora no julgamento de fundo, determinando o desmembramento. A possibilidade de decisões conflitantes em relação a corréus é própria do sistema e pode ser corrigida, pode ser afastada mediante a interposição de recurso pelo Ministério Público.

No julgamento, participaram RICARDO LEWANDOWISKI, CARMEN LÚCIA e MENEZES DIREITO.

Nesse mesmo sentido, em 19 de agosto de 2008, a 1ㄹ TURMA DO SUPREMO TRIBUNAL FEDERAL decidiu por unanimidade que:

COMPETÊNCIA PENAL - PRERROGATIVA DE FORO - EXTENSÃO - CORRÉUS - IMPROPRIEDADE. A competência do Superior Tribunal de Justiça está delimitada na Constituição Federal, não sofrendo alteração considerados institutos processuais comuns - a conexão e a continência. Precedentes do Plenário: Habeas corpus no 91.273-7/RJ, acórdão divulgado no Diário da Justiça Eletrônico de 31 de janeiro de 2008, Habeas Corpus no 89.056-3/MS, acórdão veiculado no Diário da Justiça Eletrônico de 2 de outubro de 2008, ambos de minha relatoria, e Inquérito no 1.720-5/RJ, acórdão publicado no Diário da Justiça de 14 de dezembro de 2001, relatado pelo Ministro Sepúlveda Pertence. (HC 89083/MS - Mato Grosso, DJe-025, divulgado em 6 de fevereiro de 2009)

Na oportunidade, o MINISTRO RELATOR MARCO AURÉLIO afirmou que: 
Valho-me do que tenho sustentado no Plenário no sentido de legislação instrumental referente à continência e à conexão não poder alterar competência fixada na Carta Federal: (...) As normas definidoras da competência do Supremo são de Direito estrito. Cabe ao Tribunal o respeito irrestrito ao artigo 102 da Constituição Federal. Sob o ângulo das infrações penais comuns, cumpre-lhe processar e julgar originariamente o Presidente e o Vice-Presidente da República, os membros do Congresso Nacional, os próprios ministros que o integram e o Procurador-Geral da República, mostrando-se mais abrangente a competência, a alcançar infrações penais comuns e crimes de responsabilidade, considerados os ministros de Estado, os comandantes da Marinha, do Exército e da Aeronáutica, ressalvado o disposto no artigo 52, inciso I, da Carta da República, os membros dos Tribunais Superiores, os do Tribunal de Contas da União e os chefes de missão diplomática de caráter permanente - alíneas " $b$ " e " $c$ " do inciso I do artigo 102 da Constituição Federal.

Então, forçoso é concluir que, em se tratando do curso de inquérito voltado à persecução criminal, embrião da ação a ser proposta pelo Ministério Público, a tramitação sob a direção desta Corte, presentes atos de constrição, pressupõe o envolvimento de autoridade detentora da prerrogativa de foro, de autoridade referida nas citadas alíneas " $b$ " e " $c$ ". Descabe interpretar o Código de Processo Penal conferindo-lhe alcance que, em última análise, tendo em conta os institutos da conexão ou continência, acabe por alterar os parâmetros constitucionais definidores da competência do Supremo. Argumento de ordem prática, da necessidade de evitar-se, mediante a reunião de ações penais, decisões conflitantes não se sobrepõe à competência funcional estabelecida em normas de envergadura maior, de envergadura insuplantável como são as contidas na Lei Fundamental. O argumento calcado no pragmatismo pode mesmo ser refutado considerando a boa política judiciária, isso se fosse possível colocar em segundo plano a ordem natural das coisas, tal como contemplada no arcabouço normativo envolvido na espécie.

O Supremo, hoje, encontra-se inviabilizado ante sobrecarga invencível de processos. Então, os plúrimos, a revelarem ações penais ajuizadas contra diversos cidadãos viriam a emperrar, ainda mais, a máquina existente, projetando para as calendas gregas o desfecho almejado. A problemática do tratamento igualitário - e cada processo possui peculiaridades próprias, elementos probatórios individualizados - 
não é definitiva, ante a recorribilidade prevista pela ordem jurídica e, até mesmo, a existência da ação constitucional do habeas corpus. Em síntese, somente devem tramitar sob a direção do Supremo os inquéritos que envolvam detentores de prerrogativa de foro, detentores do direito de, ajuizada a ação penal, virem a ser julgados por ele, procedendo-se ao desdobramento conforme ocorrido na espécie.

Nesse julgamento unânime, participaram os Ministros CARLOS BRITTO, RICARDO LEWANDOWISKI, CÁRMEN LÚCIA e MENEZES DIREITO.

A presente hipótese, portanto, apresenta-se substancialmente análoga aos vários pronunciamentos do SUPREMO TRIBUNAL FEDERAL, em especial de 8 de seus atuais MINISTROS, e - como ressaltado por EDWARD H. LEVI - devem levar A CORTE ao apreciar comparativamente os argumentos principais dos casos concretos, bem como seus motivos, afastando eventuais distinções consideradas razoáveis e idôneas para a conservação de ambos (The Nature of Judicial Reasoning. In: The University of Chicago Law Review, v. 32, n. 3, spring 1965, p. 400); e, escolhendo os fatos determinantes e convertendo-os em hipótese abstrata e geral (FREDERICK F. SCHAEUR. Playing by the rules: a philosophical examination of rule-based decision-making in law and in life. Oxford; New York: Clarendon, p. 183; A. SIMPSON. The ratio decidendi of a case and the doctrine of binding precedent. p. 156-159), para, então, concluir pela plena inconstitucionalidade de ampliação das competências constitucionais originárias (foro privilegiado) do SUPREMO TRIBUNAL FEDERAL por norma legal (conexão e continência); bem como por fiel observância ao Princípio da Razoabilidade.

Ressalte-se, por fim, a inaplicabilidade, na presente hipótese, da SÚMULA 704 do STF ("não viola as garantias do juiz natural, da ampla defesa e do devido processo legal a atração por continência ou conexão do processo do corréu ao for por prerrogativa de função de um dos denunciados"), uma vez que:

a) Não se refere às competências constitucionais originárias do SUPREMO TRIBUNAL FEDERAL, como flagrantemente perceptível ao analisarmos os precedentes desse enunciado;

b) Em relação às competências constitucionais originárias do SUPREMO TRIBUNAL FEDERAL, na hipótese, o denominado "foro privilegiado", 8 (OITO) dos atuais MINISTROS já se manifestaram em casos ANÁLOGOS e POSTERIORES, conforme verificado, pela impossibilidade de ampliação por normas legais e os outros 2 (DOIS) 
atuais MINISTROS não tiveram possibilidade de manifestação; o que demonstra o entendimento da própria CORTE pela inaplicabilidade da Súmula 704 à presente hipótese.

Dessa forma, está caracterizada a RAZOABILIDADE de afastamento da referida Súmula, que apresenta peculiaridades diversas da hipótese analisada, pois, para aplicação automática de um precedente, é necessário, como salienta ANA LAURA MAGALONI KERPEL, "formular uma regra geral, aplicável a um litígio similar, implica dotar de certa generalidade os fatos que deram origem à disputa" (El precedente constitucional en el sistema judicial norteamericano. Madrid: McGraw Hill, 2001. p. 83), o que não ocorre no caso em questão.

\section{(IV) Proteção dos direitos humanos. Princípio hermenêutico básico de aplicação da norma mais favorável à pessoa humana. Incidência das garantias do juiz natural e do devido processo legal ("direito de recorrer")}

As garantias fundamentais ao Devido Processo Legal e ao Juiz Natural, diferentemente do que ocorria nos textos constitucionais anteriores, foram incorporadas ao texto da Constituição brasileira de 1988.

A imparcialidade do Judiciário e a segurança do povo contra o arbítrio estatal encontram no Devido Processo Legal e no princípio do Juiz Natural, proclamadas nos incisos LV, XXXVII e LIII do art. 5ํ da Constituição Federal, suas garantias indispensáveis.

Como consagrado pelo SUPREMO TRIBUNAL FEDERAL:

O princípio da naturalidade do Juízo - que traduz significativa conquista do processo penal liberal, essencialmente fundado em bases democráticas - atua como fator de limitação dos poderes persecutórios do Estado e representa importante garantia de imparcialidade dos juízes e tribunais" (STF - 1aㅗ T. - HC no 69.601/SP - Rel. Min. CELSO DE MELLO, Diário da Justiça, Seção I, 18 dez. 1992, p. 24.377).

O juiz natural é somente aquele integrado no Poder Judiciário, com todas as garantias institucionais e pessoais previstas na Constituição Federal, devendo ser interpretado em sua plenitude, de forma a não só proibir a criação 
de Tribunais ou juízos de exceção, como também exigir respeito absoluto às regras objetivas de determinação de competência, para que não seja afetada a independência e a imparcialidade do órgão julgador.

Nesse mesmo sentido, decidiu o TRIBUNAL CONSTITUCIONAL FEDERAL ALEMÃO:

O mandamento "ninguém será privado de seu juiz natural", bem como ocorre com a garantia da independência dos órgãos judiciários, deve impedir intervenções de órgãos incompetentes na administração da Justiça e protege a confiança dos postulantes e da sociedade na imparcialidade e objetividade dos tribunais: a proibição dos tribunais de exceção, historicamente vinculada a isso, tem a função de atuar contra o desrespeito sutil a esse mandamento. Como esses dispositivos em sua essência concretizam o princípio do Estado de Direito no âmbito da constituição (organização) judiciária, elas já foram introduzidas na maioria das Constituições estaduais alemãs do século XIX, dando-lhes, assim, a dignidade de norma constitucional. O art. 105 da Constituição de Weimar deu prosseguimento a esse legado. À medida que os princípios do Estado de Direito e Separação de Poderes se foram aprimorando, também as prescrições relativas ao juiz natural foram sendo aperfeiçoadas. A lei de organização judiciária, os códigos de processo e os planos de distribuição das causas (definidos nas Geschäftsordnungen - regimentos internos) dos tribunais determinavam sua competência territorial e material, (o sistema de) a distribuição das causas, bem como a composição dos departamentos individualizados, câmaras e senados. Se originalmente a determinação "ninguém será privado de seu juiz natural" era dirigida sobretudo para fora, principalmente contra qualquer tipo de "justiça de exceção" (Kabinettsjustiz), hoje seu alcance de proteção estendeu-se também à garantia de que ninguém poderá ser privado do juiz legalmente previsto para sua causa por medidas tomadas dentro da organização judiciária. (Decisão - Urteil - do Primeiro Senado de 20 de março de 1956 - 1 BvR 479/55 Cinquenta anos de Jurisprudência do Tribunal Constitucional Federal Alemão. Coletânea Original: Jürgem Schawabe. Organização e introdução. Leonardo Martins. Konrad Adenauer - Stiffung - Programa Estado de Derecho para Sudamérica. p. 900-901). 
A garantia do Devido Processo Legal configura dupla proteção ao indivíduo, atuando tanto no âmbito material de proteção ao direito de liberdade e propriedade quanto no âmbito formal, ao assegurar-lhe paridade total de condições com o Estado-persecutor e plenitude de defesa, visando salvaguardar a liberdade individual e impedir o arbítrio do Estado.

Como salientado pelo SUPREMO TRIBUNAL FEDERAL:

A submissão de uma pessoa à jurisdição penal do Estado coloca em evidência a relação de polaridade conflitante que se estabelece entre a pretensão punitiva do Poder Público e o resguardo à intangibilidade do jus libertatis titularizado pelo réu. A persecução penal rege-se, enquanto atividade estatal juridicamente vinculada, por padrões normativos, que, consagrados pela Constituição e pelas leis, traduzem limitações significativas ao poder do Estado. Por isso mesmo, o processo penal só pode ser concebido - e assim deve ser visto - como instrumento de salvaguarda da liberdade do réu. O processo penal condenatório não é um instrumento de arbítrio do Estado. Ele representa, antes, um poderoso meio de contenção e de delimitação dos poderes de que dispõem os órgãos incumbidos da persecução penal. Ao delinear um círculo de proteção em torno da pessoa do réu - que jamais se presume culpado - , até que sobrevenha irrecorrível sentença que, condicionada por parâmetros ético-jurídicos, impõe ao órgão acusador o ônus integral da prova, ao mesmo tempo em que faculta ao acusado que jamais necessita demonstrar a sua inocência o direito de defenderse e de questionar, criticamente, sob a égide do contraditório, todos os elementos probatórios produzidos pelo MP. A própria exigência de processo judicial representa poderoso fator de inibição do arbítrio estatal e de restrição ao poder de coerção do Estado. A cláusula nulla poena sine judicio exprime, no plano do processo penal condenatório, a fórmula de salvaguarda da liberdade individual. (STF $-1^{\underline{a}} \mathrm{~T}$. $-\mathrm{HC}$ no 73.338/RJ - Rel. Min. CELSO DE MELLO - RTJ 161/264).

O Devido Processo Legal tem como corolários a Ampla Defesa e o Contraditório, que deverão ser assegurados a todos os litigantes.

Por Ampla Defesa entende-se o asseguramento que é dado ao réu de condições que lhe possibilitem trazer para o processo todos os elementos tendentes a esclarecer a verdade (direito à defesa técnica, à publicidade do 
processo, à citação, à produção ampla de provas, de ser processado e julgado pelo juiz competente, aos recursos previstos em lei, à decisão imutável, à revisão criminal) ou mesmo de calar-se, se entender necessário, enquanto o Contraditório é a própria exteriorização da ampla defesa, impondo a condução dialética do processo (par conditio), pois a todo ato produzido caberá igual direito da outra parte de opor-se-lhe ou de dar-lhe a versão que lhe convenha, ou, ainda, de fornecer uma interpretação jurídica diversa daquela feita pelo autor.

Nesse sentido, decidiu o TRIBUNAL CONSTITUCIONAL FEDERAL ALEMÃO, ao referir-se ao Princípio do Contraditório no âmbito do Devido Processo Legal:

O princípio do contraditório, elevado a direito fundamental no Art. 103 GG, é uma consequência do pensamento de Estado de direito para o âmbito do processo judicial (...) Sua inserção na Grundgesetz teve o escopo de tornar impossível abusos em processos judiciais, tais quais aqueles que foram perpetrados sob o regime nacional-socialista, reconstruindo a confiança do povo numa administração imparcial da Justiça. (Decisão - Beschluss - do Primeiro Senado de 8 de janeiro de 1959 - 1 BvR 396/53 - Cinquenta anos de Jurisprudência do Tribunal Constitucional Federal Alemão. Coletânea Original: Jürgem Schawabe. Organização e introdução. Leonardo Martins. Konrad Adenauer Stiffung - Programa Estado de Derecho para Sudamérica. p. 900-901)

A tutela judicial efetiva supõe o estrito cumprimento pelos órgãos judiciários dos princípios processuais previstos no ordenamento jurídico, em especial o Devido Processo Legal, o Contraditório e a Ampla defesa, incluído o direito a uma dupla instância em relação aos recursos existentes (DIREITO DE RECORRER), pois não são mero conjunto de trâmites burocráticos, mas um rígido sistema de garantias para as partes visando ao asseguramento de justa e imparcial decisão final.

Nesse sentido, decidiu o SUPREMO TRIBUNAL FEDERAL: “O devido processo legal compreende a existência de normas legais preestabelecidas, exercendo-se o direito de defesa, com os recursos a este inerentes, na forma das leis preexistentes, assim num devido processo legal" (STF $-2^{2}$ T. Agravo em embargos de declaração em Ag. Instr. no 181.142-1/SP - Rel. Min. CARLOS VELLOSO, Diário da Justiça, Seção I, 27 mar. 1998, p. 5). 
Esse é o mesmo entendimento do TRIBUNAL CONSTITUCIONAL ESPANHOL, ao decidir que o direito fundamental a tutela judicial efetiva compreende também sua eficácia em relação aos recursos existentes:

Como já decidido pelo Tribunal Constitucional (STC 22/87, FJ 3), as garantias constitucionais do processo são exigidas em todas e em cada uma das fases do mesmo, porque o direito a uma dupla instância supõe o direito de ser ouvido e poder defender-se em ambas, e ver-se privado de fazê-lo em uma, acarreta privação de uma possibilidade legalmente oferecida que é precisamente o poder de defender-se perante Tribunais distintos" (S. 195/90, de 29 de novembro, FJ 5 - MORI, Tomás Gui. JURISPRUDÊNCIA CONSTITUCIONAL ÍNTEGRA 1981 - 2001. Volume 1. Barcelona: Bosch. p. 512).

A doutrina reiterada do Tribunal Constitucional entende que o acesso aos recursos legalmente estabelecidos é integrante das manifestações do direito à tutela judicial efetiva, cujos requisitos processuais devem interpretar-se em um sentido mais favorável à sua efetividade. (S. 176/90, de 12 de novembro, FJ 2. No mesmo sentido: FJ 3 do STC 50/90, de 26 de março - MORI, Tomás Gui. JURISPRUDÊNCIA CONSTITUCIONAL ÍNTEGRA 1981 - 2001. Volume 1. Barcelona: Bosch. p. 511).

Dado que a tutela judicial que o artigo 24.1 da Constituição Espanhola garante não é meramente formal, mas sim efetiva, o direito aos recursos engloba o direito a utilização e efetividade dos recursos interpostos, de maneira que os órgãos judiciais não podem privar injustificadamente sua utilização. (S. 111/92, de 14 de setembro, FJ 4 - MORI, Tomás Gui. JURISPRUDÊNCIA CONSTITUCIONAL ÍNTEGRA 1981 - 2001. Volume 1. Barcelona: Bosch, p. 509)

O direito aos recursos tem parte na tutela judicial efetiva (SSTC 46/84, 110/85, 81/86, 69/87 e 130/87) e estará vulnerado quando se proíbe o indivíduo de interpor o recurso por meio de obstáculos indevidos ou por denegação injustificada, não explicitada ou devida a um erro imputável ao órgão judicial. (S. 20/91, de 31 de janeiro, FJ 3 - MORI, Tomás Gui. JURISPRUDÊNCIA CONSTITUCIONAL ÍNTEGRA 1981 - 2001. Volume 1. Barcelona: Bosch. p. 509) 
Importante ressaltar, que as garantias do JUIZ COMPETENTE E IMPARCIAL e do DIREITO DE RECURSO A INSTÂNCIA SUPERIOR quando previsto pelo ordenamento jurídico estão consagradas em nosso ordenamento jurídico, não só pela previsão expressa do princípio do Juiz Natural e do Devido Processo Legal, Contraditório e Ampla Defesa no texto constitucional, mas também pela Convenção América de Direitos Humanos - Pacto de São José da Costa Rica, devidamente incorporada em 1992; que, conforme decidiu o SUPREMO TRIBUNAL FEDERAL, tem status supralegal: "O status normativo supralegal dos tratados internacionais de direitos humanos subscritos pelo Brasil torna inaplicável a legislação infraconstitucional com ele conflitante, seja ela anterior ou posterior ao ato de adesão" (STF, Pleno, RE 349703/RS, Rel. Min. CARLOS BRITTO, decisão: 3 dezembro 2008).

Em seu artigo 8, o Pacto de São José da Costa Rica prevê expressamente o PRINCÍPIO DO JUIZ NATURAL e o DIREITO DE RECORRER:

Artigo 8. Garantias Judiciais:

1. Toda pessoa terá o direito de ser ouvida, com as devidas garantias e dentro de um prazo razoável, por um juiz ou Tribunal competente, independente e imparcial, estabelecido anteriormente por lei, na apuração de qualquer acusação penal formulada contra ela, ou na determinação de seus direitos e obrigações de caráter civil, trabalhista, fiscal ou de qualquer outra natureza.

2. Toda pessoa acusada de delito tem direito a que se presuma sua inocência enquanto não se comprove legalmente sua culpa. Durante o processo, toda pessoa tem direito, em plena igualdade, às seguintes garantias mínimas:

(...)

h) direito de recorrer da sentença para juiz ou tribunal superior.

Assim sendo, a REGRA prevista pela Constituição brasileira e reforçada pelo Pacto de São José da Costa Rica é a ampla possibilidade de utilização de todos os recursos existentes na legislação (DIREITO DE RECORRER) para garantir a tutela jurisdicional efetiva; enquanto a EXCEÇÃO ocorrerá na hipótese taxativamente prevista de competência constitucional originária do SUPREMO TRIBUNAL FEDERAL ("foro privilegiado"), prevista no artigo $102, \mathrm{I}$, " $\mathrm{b}$ " $\mathrm{e}$ " $\mathrm{c}$ ", aplicáveis somente às autoridades enumeradas em seu texto. 
Não será possível, sob pena de grave ferimento à Constituição Federal e à Declaração Americana de Direitos Humanos, APLICAR NORMA LEGISLATIVA ORDINÁRIA (CPP - conexão ou continência) às hipóteses de "foro privilegiado", de maneira a subtrair réus, cuja competência penal originária não seja do SUPREMO TRIBUNAL FEDERAL, de seu JUÍZO NATURAL, sob pena de - além das inconstitucionalidades já citadas efetivar-se GRAVE RESTRIÇÃO PROTETIVA AOS DIREITOS HUMANOS, referente ao DEVIDO PROCESSO LEGAL, em especial ao DIREITO DE RECORRER.

O próprio SUPREMO TRIBUNAL FEDERAL já consagrou que, no âmbito protetivo dos Direitos Humanos, o princípio hermenêutico básico é a aplicação da norma mais favorável à pessoa humana:

TRATADOS INTERNACIONAIS DE DIREITOS HUMANOS: AS SUAS RELAÇÕES COM O DIREITO INTERNO BRASILEIRO E A QUESTÃO DE SUA POSIÇÃO HIERÁRQUICA. - A Convenção Americana sobre Direitos Humanos (Art. 7ํㅡ, no 7). Caráter subordinante dos tratados internacionais em matéria de direitos humanos e o sistema de proteção dos direitos básicos da pessoa humana. - Relações entre o direito interno brasileiro e as convenções internacionais de direitos humanos (CF, art. 5으 e $\S 2^{\circ} \circ$ e $3^{\circ}$ ). Precedentes. - Posição hierárquica dos tratados internacionais de direitos humanos no ordenamento positivo interno do Brasil: natureza constitucional ou caráter de supralegalidade? EntendimentodoRelator,Min.CELSODEMELLO, queatribuihierarquia constitucional às convenções internacionais em matéria de direitos humanos. A INTERPRETAÇÃO JUDICIAL COMO INSTRUMENTO DE MUTAÇÃO INFORMAL DA CONSTITUIÇÃO. - A questão dos processos informais de mutação constitucional e o papel do Poder Judiciário: a interpretação judicial como instrumento juridicamente idôneo de mudança informal da Constituição. A legitimidade da adequação, mediante interpretação do Poder Judiciário, da própria Constituição da República, se e quando imperioso compatibilizá-la, mediante exegese atualizadora, com as novas exigências, necessidades e transformações resultantes dos processos sociais, econômicos e políticos que caracterizam, em seus múltiplos e complexos aspectos, a sociedade contemporânea. HERMENÊUTICA E DIREITOS HUMANOS: A NORMA MAIS FAVORÁVEL COMO CRITÉRIO QUE DEVE REGER A INTERPRETAÇÃO DO PODER JUDICIÁRIO. - Os 
magistrados e Tribunais, no exercício de sua atividade interpretativa, especialmente no âmbito dos tratados internacionais de direitos humanos, devem observar um princípio hermenêutico básico (tal como aquele proclamado no Artigo 29 da Convenção Americana de Direitos Humanos), consistente em atribuir primazia à norma que se revele mais favorável à pessoa humana, em ordem a dispensar-lhe a mais ampla proteção jurídica. - O Poder Judiciário, nesse processo hermenêutico que prestigia o critério da norma mais favorável (que tanto pode ser aquela prevista no tratado internacional como a que se acha positivada no próprio direito interno do Estado), deverá extrair a máxima eficácia das declarações internacionais e das proclamações constitucionais de direitos, como forma de viabilizar o acesso dos indivíduos e dos grupos sociais, notadamente os mais vulneráveis, a sistemas institucionalizados de proteção aos direitos fundamentais da pessoa humana, sob pena de a liberdade, a tolerância e o respeito à alteridade humana tornarem-se palavras vãs. (STF - 2a T. - HC 96772/SP - Rel. Min. Celso de Mello, DJe-157, 21-8-2009)

O INTÉRPRETE MAIOR DA CARTA MAGNA deve evitar contradições entre princípios, preceitos e regras estabelecidos em seu texto (Método da Unidade da Constituição), pois, como salienta CANOTILHO, o intérprete deve "considerar a Constituição na sua globalidade e procurar harmonizar os espaços de tensão existentes entre as normas constitucionais a concretizar" (Direito constitucional e teoria da Constituição. 2. ed. Coimbra: Almedina, 1998).

A CORTE SUPREMA deverá, portanto, aplicar a interdependência e complementaridade das normas constitucionais, que não deverão, como nos lembra GARCIA DE ENTERRIA, ser interpretadas isoladamente, sob pena de desrespeito à vontade do legislador constituinte (Reflexiones sobre la ley e los princípios generales del derecho. Madri: Civitas, 1996. p. 30), sendo impositivo e primordial a análise semântica do texto Magno, garantindo àqueles que não possuam o denominado "foro privilegiado" perante o SUPREMO TRIBUNAL FEDERAL, como destacado pelo MINISTRO CELSO DE MELLO, "primazia à norma que se revele mais favorável à pessoa humana, em ordem a dispensarlhe a mais ampla proteção jurídica", visando a consagração do direito fundamental a tutela judicial efetiva.

A plena compatibilidade do artigo 102, I, "b" e "c" da Constituição Federal (REGRA EXCEPCIONAL DO “FORO PRIVILEGIADO”) com os princípios do DEVIDO PROCESSO LEGAL, inclusive o DIREITO DE RECORRER, 
e do JUIZ NATURAL guardará sua "coerência lógica" (GORDILLO), sua "prudência, proporção, indiscriminação, proteção e não arbitrariedade" (DROMI), com a aplicação de "critérios racionais, sensatos e coerentes" (JOSÉ EDUARDO CARDOSO), que determinem A INCOMPETÊNCIA DO SUPREMO TRIBUNAL FEDERAL para o processo e julgamento de réus que NÃO CONSTEM taxativamente nas previsões constitucionais de suas competências penais originárias.

Dessa maneira, são apresentadas as seguintes respostas aos quesitos:

QUESITO 1 - É possível ao legislador ordinário ampliar as competências originárias do Supremo Tribunal Federal?

RESPOSTA: As competências originárias do SUPREMO TRIBUNAL FEDERAL são expressas e taxativamente previstas pela Constituição Federal, não se admitindo ampliação pelo legislador ordinário.

QUESITO 2 - É possível a ampliação das competências originárias do Supremo Tribunal Federal com base na Teoria dos Poderes Implícitos?

RESPOSTA: As competências originárias do SUPREMO TRIBUNAL FEDERAL são expressas e taxativamente previstas pela Constituição Federal, não se admitindo ampliação com base em supostas competências originárias implícitas, uma vez que não é possível a aplicação da Teoria dos Poderes Implícitos à nossa Corte Suprema, pois suas competências se encontram em rol taxativamente descrito no texto constitucional.

QUESITO 3 - É possível a ampliação das competências penais originárias do Supremo Tribunal Federal com base em interpretação de legislação ordinária já existente (regras legais de conexão e continência), permitindo que a Corte processe e julgue réus não previstos no art. 102, inciso I, " $a$ " e " $b$ " da Constituição Federal?

RESPOSTA: As competências originárias do SUPREMO TRIBUNAL FEDERAL, conforme já respondido no Quesito 1, são expressas e taxativamente previstas pela Constituição Federal, não se admitindo, inclusive, por qualquer interpretação da legislação ordinária, que, visando garantir maior alcance a institutos infraconstitucionais (como na espécie, conexão e continência), acabe por permitir que, de maneira reflexa, o rol taxativo de autoridades submetidas à competência penal originária da Corte Suprema possa ser ampliado.

QUESITO 4 - A Súmula 704 do Supremo Tribunal Federal ("não viola as garantias do juiz natural, da ampla defesa e do devido processo legal a atração por continência ou conexão do processo do corréu ao foro por prerrogativa de função de um dos denunciados") se aplica em relação às competências penais originárias da Corte? 
RESPOSTA: A Súmula 704 não se refere às competências penais originárias do SUPREMO TRIBUNAL FEDERAL, como flagrantemente perceptível ao analisarmos os precedentes desse enunciado, não tendo, portanto, aplicabilidade em relação ao artigo 102, I, "a" e "b" da Constituição Federal. Na hipótese de coautoria em infrações penais de competência originária do Supremo Tribunal Federal, deverá ocorrer o desmembramento em relação àqueles corréus que não possuam "foro privilegiado", aplicando-se o princípio hermenêutico básico na proteção dos Direitos Humanos, qual seja a aplicação da norma mais favorável à pessoa humana, com ampla incidência das garantias do Juiz Natural e do Devido Processo Legal. 